\title{
Article \\ Phytochemical Profile of Opuntia ficus-indica (L.) Mill Fruits (cv. 'Orito') Stored at Different Conditions
}

\author{
Francisca Hernández ${ }^{1, * \mathbb{D}}$, Lucía Andreu-Coll ${ }^{1}$, Andreia Bento-Silva ${ }^{2,3} \mathbb{D}$, Ana Teresa Serra ${ }^{4,5}$, Pedro Mena ${ }^{6} \mathbb{D}$, \\ Pilar Legua ${ }^{1}$ (D) and Maria Rosario Bronze $2,4,5$
}

1 Grupo de Investigación en Fruticultura y Técnicas de Producción, Centro de Investigación e Innovación Agroalimentaria y Agroambiental (CIAGRO-UMH), Miguel Hernández University, Carretera de Beniel, km 15 3.2, 03312 Orihuela, Alicante, Spain; lucia.andreu1@gmail.com (L.A.-C.); p.legua@umh.es (P.L.)

2 Instituto de Investigação do Medicamento, Faculdade de Farmácia, Universidade de Lisboa, Avenida Prof. Gama Pinto, 1649-003 Lisboa, Portugal; abentosilva@ff.ulisboa.pt (A.B.-S.); mbronze@ibet.pt (M.R.B.)

3 Departamento de Ciências Farmacêuticas e do Medicamento, Faculdade de Farmácia, Universidade de Lisboa, Av. das Forças Armadas, 1649-003 Lisboa, Portugal

4 Laboratory of Phytochemicals in Physiology, Department of Food Science and Drugs, University of Parma, Medical School, Building C, Via Volturno, 39, 43125 Parma, Italy; tserra@ibet.pt

5 Instituto de Biologia Experimental e Tecnológica, Avenida da República, Estação Agronómica Nacional, 2780-157 Oeiras, Portugal

6 Instituto de Tecnologia Química e Biológica, Universidade Nova de Lisboa, Avenida da República, Estação Agronómica Nacional, 2780-157 Oeiras, Portugal; pedromiguel.menaparreno@unipr.it

* Correspondence: francisca.hernandez@umh.es

check for updates

Citation: Hernández, F.; Andreu-Coll, L.; Bento-Silva, A.; Serra, A.T.; Mena, P.; Legua, P.; Bronze, M.R. Phytochemical Profile of Opuntia ficus-indica (L.) Mill Fruits (cv. 'Orito') Stored at Different Conditions. Foods 2022, 11, 160. https://doi.org/10.3390/ foods 11020160

Academic Editor: Jinhe Bai

Received: 18 November 2021

Accepted: 5 January 2022

Published: 8 January 2022

Publisher's Note: MDPI stays neutral with regard to jurisdictional claims in published maps and institutional affiliations.

Copyright: (C) 2022 by the authors. Licensee MDPI, Basel, Switzerland. This article is an open access article distributed under the terms and conditions of the Creative Commons Attribution (CC BY) license (https:// creativecommons.org/licenses/by/ $4.0 /)$.

\begin{abstract}
This research analyzed the phytochemical profile of prickly pear fruits from 'Orito' cultivar stored under cold conditions $\left(2{ }^{\circ} \mathrm{C}, 85-90 \% \mathrm{RH}\right)$ and shelf-life conditions at room temperature (stored at $20^{\circ} \mathrm{C}$ for three days after cold storage) for 28 days, mimicking the product life cycle. A total of 18 compounds were identified and quantitated through HPLC-DAD-MS/MS (High-Performance Liquid Chromatographic -Diode Array Detector- Mass Spectrometry) analyses. Phenolic acids such as eucomic acid and betalains such as indicaxanthin were the predominant chemical families, and piscidic acid was the most abundant compound. During cold storage, the content of eucomic acid isomer/derivative and syringaresinol increased, and citric acid decreased, which could be caused by the cold activation of the phenylalanine ammonia-lyase (PAL) and polyphenol oxidase (PPO) enzymes. However, no significant differences were found in the content of these compounds during shelf-life storage. These results showed that 'Orito' fruit marketability would be possible up to 28 days after harvesting, retaining its profile, which is rich in bioactive compounds.
\end{abstract}

Keywords: prickly pear; HPLC-MS; betalains; phenolic acid; lignans; antioxidants

\section{Introduction}

Prickly pear is a sweet flavory fleshy berry with thick peel and many seeds, varying in size, shape, and color. This fruit has excellent nutritional properties, is low in calories and high in bioactive compounds, such as betalains, phenolics and vitamins, which show antioxidant activity and are related with health benefits and the prevention of some chronic diseases, due to their anti-inflammatory, antidiabetic, neuroprotective and antiproliferative activities, among others [1-3].

Besides its consumption as a fresh fruit product, prickly pear presents a wide range of applications, including animal feeding, developing of processed products such as juices and jams, and production of bioethanol and biogas. Due to the high concentration of bioactive compounds, especially (poly)phenolic compounds, prickly pear can be used in the nutraceutical, pharmaceutic, and cosmetics industries [4-6]. The (poly)phenolic composition of prickly pear fruits and derived products has been well described, and 
includes phenolic acids, flavonoids, and lignans, among others [2,7]. In addition, fruits present high amounts of betalains [2].

Postharvest conservation affects quality characteristics of fruit and vegetables because they continue their metabolic changes after harvesting. In non-climacteric fruits, these changes can be undesirable and cause quality losses $[8,9]$. For prickly pear fruit, chilling injuries, microbial growth, loss of firmness and weight loss are the major deterioration factors that affect this fruit after harvesting and during postharvest conservation, its quality depending pretty much on handling and storage conditions $[8,10]$.

Although prickly pear was classified as a non-climacteric fruit, classification of climacteric and non-climacteric fruit is not absolute, and genotypes and cultivars of some species can show both patterns [11,12]. 'Orito' fruit, the commercial Spanish cultivar studied in this work, showed a suppressed climacteric pattern in ethylene production and respiration rate similar to some cultivars of plum, which showed no increase in respiration rate or in ethylene production associated with ripening [13-15]. In a previous work we demonstrated that 'Orito' fruit maintained its quality parameters in desirable values up to 28 days, both in cold conditions $\left(2{ }^{\circ} \mathrm{C}, 85-90 \%\right.$ relative humidity, $\left.\mathrm{RH}\right)$ and during shelf-life storage, whereas the total phenolic content increased during the shelf life conditions [13]. However, to this point in time there are no studies evaluating the (poly)phenolic composition of prickly pear fruits during storage. The aim of this work was to evaluate the impact of storage conditions and shelf-life on the bioactive compound profile of 'Orito' fruit, with a particular focus on the (poly)phenolic fraction. The results obtained will contribute to select the best shelf-life and storage conditions to improve marketability of the fruits and to develop further strategies focused on the valorization of the phytochemical profile of this species.

\section{Materials and Methods}

\subsection{Plant Material and Sample Processing}

Fruits of a commercial cultivar of Opuntia ficus-indica (L.) Mill., called 'Orito', were used for this study. The fruits were hand-harvested in mid-August 2017 in a commercial farm $\left(38^{\circ} 23^{\prime} 30.7^{\prime \prime} \mathrm{N}, 0^{\circ} 40^{\prime} 13.0^{\prime \prime} \mathrm{W}\right.$, Orito, Alicante, Spain). The fruit was collected at the commercial ripening stage and was carried in cold to the laboratory for sample preparing and further analyses. At the laboratory, fruits were brushed to remove the spines. Next, 540 fruits were chosen based on homogeneous size, color, and by the absence of visual defects. These fruits were indiscriminately divided into 27 lots of 20 fruit, each being a biological replicate.

Three lots were used for evaluating the fruit properties at. The rest of the lots were stored in a refrigeration chamber at $2{ }^{\circ} \mathrm{C}$ and $85-90 \% \mathrm{RH}$ (cold conservation). Of these, three lots were reserved for evaluation at 7, 14, 21, and 28 days after harvest. Besides, the other three lots for each time point were taken and disposed of at $20^{\circ} \mathrm{C}$ for three days to study shelf life (SL). The pulp of the fruits was cut into small pieces to achieve a uniform sample of each biological replicate and were directly frozen at $-80^{\circ} \mathrm{C}$. After freezing, samples were freeze-dried in an Alpha 2.4 freeze drier (Christ Alpha 2.4; Braum Biotech, Osterode am Harz, Germany) for $24 \mathrm{~h}$ at a reduced pressure of 0.220 mbar. The temperature in the drying chamber was $-25^{\circ} \mathrm{C}$, while the heating plated reached $15{ }^{\circ} \mathrm{C}$. At the end of the freeze-drying, the samples were powdered and packed in vacuum until analysis. The information about samples (code and description) is summarized in Table 1. 
Table 1. Description of samples of $O$. ficus-indica (L.) Mill analyzed in this study.

\begin{tabular}{cc}
\hline Code & Description \\
\hline D0 & Day 0 (harvest) \\
D7 & seven days in cold conservation \\
D7SL & seven days in cold conservation + three days at room temperature to study shelf life \\
D14 & 14 days in cold conservation \\
D14SL & 14 days in cold conservation + three days at room temperature to study shelf life \\
D21 & 21 days in cold conservation \\
D21SL & 21 days in cold conservation + three days at room temperature to study shelf life \\
D28 & 28 days in cold conservation \\
D28SL & 28 days in cold conservation + three days at room temperature to study shelf life \\
\hline
\end{tabular}

\subsection{Extraction of Phytochemical Compounds}

Phytochemicals were extracted following the protocol of Mena et al. [2]. Briefly, $200 \mathrm{mg}$ of freeze-dried powder were mixed with $1 \mathrm{~mL}$ of $80 \%$ aqueous methanol acidified with formic acid (1\%). This mixture was sonicated for $25 \mathrm{~min}$, and the mixture was then centrifuged at $10,480 \times g$ for $5 \mathrm{~min}$ at room temperature. After supernatant collection, two additional extractions were executed for each sample with an additional $0.5 \mathrm{~mL}$ of the extraction solvent, as described above. All three supernatants were pooled and filtered through a $0.45 \mu \mathrm{m}$ Millipore filter (Billerica, MA, USA) before HPLC-MS analysis.

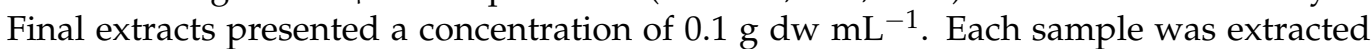
in triplicate.

\subsection{HPLC-DAD (High-Performance Liquid Chromatographic-Diode Array Detector) Analysis}

The extracts were analysed in a HPLC Dionex Ultimate 3000 equipped with a C-18 LiChrospher ${ }^{\circledR} 100$ RP-18 $(5 \mu \mathrm{m})$ column $(250 \times 4.0 \mathrm{~mm})$ (Sigma-Aldrich, San Luis, MO, USA) operating at $35^{\circ} \mathrm{C}$, coupled to a DAD-3000 detector (Thermo Scientific, MA, USA). The mobile phase consisted of water-formic acid $(0.5 \% \mathrm{v} / \mathrm{v})$ (eluent A) and acetonitrile (90\%) + formic acid $(0.5 \%)+$ water (eluent $B$ ) at a flow rate of $0.3 \mathrm{~mL} / \mathrm{min}$ with an injection volume of $20 \mu \mathrm{L}$. The gradient used is summarized in 'Supplementary Materials Table S1' section.

\subsection{HPLC-DAD-MS/MS Analysis}

Samples were also analysed by an HPLC-DAD-MS/MS system: a Waters Alliance 2695 (Waters ${ }^{\circledR}$, Dublin, Ireland) separation module with an autosampler $(20 \mu \mathrm{L}$ injection volume), a quaternary pump and a solvent degasser, coupled to a Photodiode Array Detector Waters 996 PDA (Waters, Dublin, Ireland) scanning wavelength absorption between 210 and $600 \mathrm{~nm}$. A LiChrospher ${ }^{\circledR} 100 \mathrm{RP}-185 \mu \mathrm{m}$ column at $35^{\circ} \mathrm{C}$ (stabilized by a column oven) was used. Tandem mass spectrometry (MS/MS) detection was carried out with a Micromass ${ }^{\circledR}$ Quattro Micro triple quadrupole (Waters, Dublin, Ireland), using an electrospray ionization source in both positive (ESI+) and negative (ESI-) modes. A full scan mode $(m / z: 60-1100)$ record was applied for the mass spectra of the compounds separated by HPLC, using a collision energy of $20 \mathrm{eV}$. The HPLC gradient method and eluents are described in 'Supplementary Materials Table S2' section. The MS/MS conditions, as source temperature, capillary and source voltages have been previously described by Katsinas et al. [16]. For data acquisition and processing, MassLynx ${ }^{\circledR} 4.1$ software (Waters, Dublin, Ireland) was used.

\subsection{Statistical Analyses}

One-way analysis of variance (ANOVA) and multiple-range tests were used for samples comparison. The data were compared throughout cold storage and under shelf life conditions independently (from day 0 to day 28) and each day was independently compared under cold and shelf life conditions. The method used to discriminate among the means (Multiple Range Test) was the Tukey's least significant difference procedure. 
Significance was defined at $p \leq 0.05$. Statistical analysis was performed using XLSTAT software version 9 (Microsoft Corporation, Redmond, WA, USA) [17].

\section{Results and Discussion}

The exhaustive analysis of $O$. ficus-indica fruit pulp phytochemical composition allowed the tentative identification of 18 compounds (Table 2). Taking into account the compounds identified in prickly pear fruit pulp, betalains (four compounds, namely 14,15 and 17), phenolic acids (nine compounds, of which 3-7 were phenylpyruvic acids and 8 and 13 were hydroxycinnamic acids), lignans (four compounds, 9-12) were the most relevant classes of phytochemicals. In addition, some other compounds such as organic acids (compounds 1 and 2), an amino acid (16) and a prenylflavonoid (compound 18) were detected. These compounds were identified based on their retention time, fragmentation patterns obtained from mass spectra and by comparing their mass spectral characteristics with the available literature.

Table 2. Retention time (RT) and characteristic MS ions of phytochemical compounds identified in prickly pear fruits during cold and shelf life storage.

\begin{tabular}{|c|c|c|c|c|c|c|}
\hline Id. & Compounds & $\begin{array}{c}\mathrm{RT} \\
(\mathrm{min})\end{array}$ & $\begin{array}{l}\text { Percursor Ion } \\
{[\mathrm{M}-\mathrm{H}]^{-} \text {or }} \\
{[\mathrm{M}]^{+}(m / z)}\end{array}$ & $\lambda \max (\mathrm{nm})$ & Product Ions ${ }^{\dagger}(\mathrm{m} / \mathrm{z})$ & References \\
\hline 1 & L-Malic acid & 8.10 & $133^{+}$ & 272 & 71 & [2] \\
\hline 2 & Citric acid & 11.17 & 191 & 466,270 & $111,87,85,43,41,67,57$ & [2] \\
\hline 3 & Piscidic acid & 19.20 & 255 & 466,274 & $73,107,165,58,93,133,179$ & {$[2,18]$} \\
\hline 4 & Dicaffeoylferulic acid isomer 1 & 26.08 & 517 & 278 & 187,239 & [19] \\
\hline 5 & Eucomic acid & 27.75 & 239 & 274 & $107,133,149,177,179,87$ & {$[2,18,20]$} \\
\hline 6 & Dicaffeoylferulic acid isomer 2 & 27.82 & 517 & 274 & 239,198 & [19] \\
\hline 7 & Eucomic acid isomer/derivative & 29.89 & 239 & 268 & 179,91 & \\
\hline 8 & Ferulic acid derivative & 30.45 & 517 & 268 & $175,193,235$ & [2] \\
\hline 9 & Guaiacyl(t8-O-4)guaiacyl-hexoside isomer 1 & 30.45 & 537 & 268 & $195,324,165$ & [2] \\
\hline 10 & Guaiacyl(t8-O-4)guaiacyl-hexoside isomer 2 & 32.26 & 537 & 273 & 375 & [2] \\
\hline 11 & Secoisolariciresinol-hexoside & 35.19 & 523 & 276 & 361,447 & [2] \\
\hline 12 & Syringaresinol & 46.80 & 417 & 275 & $181,387,166,123$ & {$[2]$} \\
\hline 13 & Feruloyl derivative & 57.98 & 562 & 321,285 & - & [2] \\
\hline 14 & Betaxanthin- proline (indicaxanthin) isomer 1 & 19.85 & 309 & 480 & $106,70,263,217$ & {$[21,22]$} \\
\hline 15 & Betaxanthin-proline (indicaxanthin) isomer 2 & 20.51 & 309 & 480 & $106,70,263,217$ & {$[21,22]$} \\
\hline 16 & Tryptophan & 31.61 & 205 & 278 & $118,146,132,170$ & {$[23]$} \\
\hline 17 & Phenylalanine-betaxanthin & 37.28 & 359 & 480 & $315,313,131$ & [22] \\
\hline 18 & $\begin{array}{c}\text { Prenylnaringenin } \\
\text { (trihydroxy-8-prenylflavanone) }\end{array}$ & 38.27 & 341 & 275 & $137,175,251,119,311$ & [24] \\
\hline
\end{tabular}

${ }^{+}$Compounds 1-13 were identified in negative ionization mode, while compounds 14-18 were detected in positive mode. RT, retention time.

Piscidic acid (component 3) was the compound which showed the largest area (Table 3) and some authors reported this acid as the most abundant compound in prickly pear fruits [21]. This compound showed no significant changes during cold and shelf life storage, and neither did eucomic acid (component 5). Piscidic acid is a chelator of iron which shows strong antioxidant activity, and its presence is unusual in nature, being restricted to crassulacean acid metabolism (CAM) and succulent plants [21,22]. Although there are no data about the antioxidant properties of eucomic acid, Mata et al. [22] suggested that, due to their structure, it may be similar to that of piscidic acid. 
Table 3. Average of area (mAU*min) for each component detected in O. ficus-indica (L.) Mill. samples at $280 \mathrm{~nm}$, except components $14-15$ (474 nm), during cold and shelf life storage.

\begin{tabular}{|c|c|c|c|c|c|c|c|}
\hline Id. & Component & & D0 & D7 & D14 & D21 & D28 \\
\hline \multirow[t]{2}{*}{1} & L-Malic acid & After cold storage & $7.67 \pm 0.86 \mathrm{~A}^{+}$ & $6.23 \pm 0.68 \mathrm{Aa}$ & $11.32 \pm 2.50 \mathrm{Aa}$ & $8.71 \pm 2.58 \mathrm{Aa}$ & $8.0 \pm 2.38 \mathrm{Aa}$ \\
\hline & & After shelf life & $7.67 \pm 0.86 \mathrm{~A}^{\dagger}$ & $7.93 \pm 1.25 \mathrm{Aa}$ & $15.39 \pm 2.09 \mathrm{Aa}$ & $10.87 \pm 3.15 \mathrm{Aa}$ & $6.04 \pm 3.20 \mathrm{Aa}$ \\
\hline \multirow[t]{2}{*}{2} & Citric acid & After cold storage & $45.3 \pm 3.94 \mathrm{~B}$ & $44.62 \pm 2.01 \mathrm{Ba}$ & $29.45 \pm 4.05 \mathrm{Aa}$ & $24.50 \pm 4.18 \mathrm{Aa}$ & $28.58 \pm 6.65 \mathrm{Aa}$ \\
\hline & & After shelf life & $45.3 \pm 3.94 \mathrm{~A}$ & $40.40 \pm 3.2 \mathrm{Aa}$ & $40.18 \pm 4.92 \mathrm{Ab}$ & $40.21 \pm 4.04 \mathrm{Ab}$ & $32.49 \pm 4.52 \mathrm{Aa}$ \\
\hline \multirow[t]{2}{*}{3} & Piscidic acid & After cold storage & $166.85 \pm 25.99 \mathrm{~A}$ & $172.18 \pm 5.59 \mathrm{Aa}$ & $161.62 \pm 11.07 \mathrm{Aa}$ & $158.07 \pm 7.99 \mathrm{Aa}$ & $173.45 \pm 3.33 \mathrm{Aa}$ \\
\hline & & After shelf life & $166.85 \pm 25.99 \mathrm{~A}$ & $180.19 \pm 17.40 \mathrm{Aa}$ & $162.25 \pm 4.10 \mathrm{Aa}$ & $150.47 \pm 16.59 \mathrm{Aa}$ & $171.55 \pm 26.44 \mathrm{Aa}$ \\
\hline \multirow[t]{2}{*}{5} & Eucomic acid & After cold storage & $43.77 \pm 13.25 \mathrm{~A}$ & $42.10 \pm 1.67 \mathrm{Aa}$ & $37.81 \pm 2.88 \mathrm{Aa}$ & $42.66 \pm 6.14 \mathrm{Aa}$ & $37.66 \pm 3.32 \mathrm{Aa}$ \\
\hline & & After shelf life & $43.77 \pm 13.25 \mathrm{~A}$ & $47.84 \pm 4.71 \mathrm{Aa}$ & $42.90 \pm 12.43 \mathrm{Aa}$ & $30.96 \pm 2.81 \mathrm{Aa}$ & $40.47 \pm 7.38 \mathrm{Aa}$ \\
\hline 7 & $\begin{array}{c}\text { Eucomic acid } \\
\text { isomer/derivative }\end{array}$ & After cold storage & $19.85 \pm 1.45 \mathrm{~A}$ & $24.19 \pm 0.97 \mathrm{Ba}$ & $25.52 \pm 0.54 \mathrm{Ba}$ & $24.32 \pm 0.73 \mathrm{Ba}$ & $25.25 \pm 0.89 \mathrm{Ba}$ \\
\hline \multirow{3}{*}{8} & & After shelf life & $19.85 \pm 1.45 \mathrm{~A}$ & $24.16 \pm 1.67 \mathrm{Aa}$ & $25.84 \pm 1.27 \mathrm{Aa}$ & $22.77 \pm 3.58 \mathrm{Aa}$ & $24.54 \pm 2.20 \mathrm{Aa}$ \\
\hline & Ferulic acid derivative & After cold storage & $50.35 \pm 2.97 \mathrm{AB}$ & $49.55 \pm 2.35 \mathrm{Aa}$ & $58.00 \pm 1.66 \mathrm{Ba}$ & $56.66 \pm 2.77 \mathrm{ABa}$ & $52.49 \pm 2.21 \mathrm{ABa}$ \\
\hline & & After shelf life & $50.35 \pm 2.97 \mathrm{~A}$ & $63.56 \pm 7.57 \mathrm{Ab}$ & $57.95 \pm 6.30 \mathrm{Aa}$ & $59.43 \pm 3.40 \mathrm{Aa}$ & $57.81 \pm 6.68 \mathrm{Aa}$ \\
\hline \multirow[t]{2}{*}{12} & Syringaresinol & After cold storage & $27.28 \pm 1.61 \mathrm{~A}$ & $31.48 \pm 0.37 \mathrm{Ba}$ & $33.99 \pm 0.67 \mathrm{Ba}$ & $31.42 \pm 0.71 \mathrm{Ba}$ & $33.43 \pm 0.83 \mathrm{Ba}$ \\
\hline & & After shelf life & $27.28 \pm 1.61 \mathrm{~A}$ & $30.77 \pm 2.56 \mathrm{Aa}$ & $32.74 \pm 0.20 \mathrm{Aa}$ & $29.87 \pm 4.35 \mathrm{Aa}$ & $34.15 \pm 3.14 \mathrm{Aa}$ \\
\hline \multirow[t]{2}{*}{13} & Feruloyl derivative & After cold storage & $6.79 \pm 2.11 \mathrm{~A}$ & $5.74 \pm 1.20 \mathrm{Aa}$ & $8.38 \pm 1.97 \mathrm{Aa}$ & $8.25 \pm 1.03 \mathrm{Aa}$ & $6.55 \pm 1.27 \mathrm{Aa}$ \\
\hline & & After shelf life & $6.79 \pm 2.11 \mathrm{~A}$ & $11.55 \pm 1.77 \mathrm{Aa}$ & $7.38 \pm 1.55 \mathrm{Aa}$ & $9.42 \pm 2.16 \mathrm{Aa}$ & $8.77 \pm 2.92 \mathrm{Aa}$ \\
\hline \multirow[t]{2}{*}{ 14-15 } & $\begin{array}{l}\text { Betaxanthin-proline } \\
\text { (indicaxanthin) } \\
\text { isomers } 1 \text { and } 2\end{array}$ & After cold storage & $21.00 \pm 1.03 \mathrm{~A}$ & $25.55 \pm 1.62 \mathrm{Aa}$ & $23.42 \pm 3.13 \mathrm{Aa}$ & $23.66 \pm 1.01 \mathrm{Aa}$ & $23.52 \pm 2.14 \mathrm{Aa}$ \\
\hline & & After shelf life & $21.00 \pm 1.03 \mathrm{~A}$ & $27.72 \pm 4.29 \mathrm{Aa}$ & $25.67 \pm 1.32 \mathrm{Aa}$ & $21.46 \pm 2.04 \mathrm{Aa}$ & $22.15 \pm 1.15 \mathrm{Aa}$ \\
\hline 16 & & After shelf life & $19.21 \pm 6.51 \mathrm{~A}$ & $15.73 \pm 1.25 \mathrm{Aa}$ & $21.71 \pm 2.65 \mathrm{Aa}$ & $14.85 \pm 3.25 \mathrm{Aa}$ & $18.22 \pm 2.81 \mathrm{Aa}$ \\
\hline
\end{tabular}

${ }^{+}$Data are the mean \pm standard error SE $(n=3)$. The different capital letters within the rows $(\mathrm{A}, \mathrm{B}, \mathrm{AB})$ indicates significant differences according to the Tukey test $(p<0.05)$ throughout cold and shelf life storage. Lowercase letters within the columns $(a, b)$ indicate significant differences according to the Tukey test $(p<0.05)$ each day independently compared under cold and shelf life conditions. 
No major changes were observed for most of the phytochemicals during the cold storage of 'Orito' fruit, while three-day shelf life after storage did not change the phytochemical profile of prickly pear fruits (Table 3). The content of eucomic acid isomer/derivative (7) and syringaresinol (12) increased, and the content of citric acid (2) decreased (Table 3). Compounds 7 and 12 increased their content starting on day seven of cold storage, and from this moment they remained stable until the end of cold storage. However, in these compounds no significant differences were found in the comparison of cold and shelf life in the same day of storage. Ferulic acid derivative (8) decreased its content after seven days of cold storage, increased by day 21 , and then decreased slightly again at the end of cold storage.

Compound 12, which content increased under cold storage, pertained to the family of lignans, a group of secondary metabolites recognized as phytoestrogens and present in a great variety of plants, including seeds and some botanical berries as prickly pear. They are polyphenolic compounds related with the phenylalanine metabolism and show antioxidant properties related to anti-inflammatory, antitumoral and antiviral effects, among others $[25,26]$.

Phenolic acids, as compounds $3-8$ and 13 , are aromatic secondary plant metabolites and are also widely spread throughout vegetables. They are related to color, sensory qualities, nutritional and antioxidant properties. There is some evidence of their role in the inhibition of oxidative damage diseases such as coronary heart disease, stroke and cancers $[27,28]$. Most of them did not change from being stored, which agrees with the results of this study, in which only compounds 7 and 8 changed during cold storage, and all of them remained stable under shelf-life conditions.

Betalains, as compounds 14,15 and 17, are water-soluble pigments responsible for the red or yellow color of fruits and other botanical parts such as flowers and leaves of species belonging to the order of Caryophyllales, in which prickly pear is included. These compounds, which remained stable under cold and shelf-life conditions, also show antioxidant activity and may provide health benefits to consumers [29,30].

Betalains, phenolic acids and lignans are compounds related with the phenylalanine metabolism. Phenylalanine is an aromatic amino acid which is a precursor or secondary metabolite in plants, serving as a building block of many compounds essential to plant structure, reproduction, defense, and communication [31]. Phenylalanine ammonia-lyase (PAL) is an enzyme regulating the synthesis and accumulation of phenolic compounds in plants. This enzyme is stimulated by cold, thus, the variation of phenolic content in fruits during cold storage might be influenced by its activation. Some studies reported the increase of PAL activity during cold storage, in parallel to the increase in phenolic compounds in strawberry, artichokes and blueberries [32-34].

Citric acid (2) content decreased during cold storage. This decrease could be attributed to the effect of the enzyme polyphenol oxidase (PPO), which may affect the concentration of other organic acids and is stimulated by cold storage [35].

There were no detected chilling injuries in 'Orito' fruit as they were found in other cultivars such as 'Copena-Torreoja', as studied by Corrales-García et al. [10]. In this sense, their results [10] showed 100\% injury from chilling after the first month of cold storage. Other cultivars studied by these authors showed chilling injuries after two or three months of cold storage. Although visually 'Orito' fruit did not show such chilling-injury signs as browning, either under cold nor shelf life conditions, PAL and PPO enzymes are related to physiological disorders during cold storage in some fruits such as apples, mandarin-fruits and plums $[33,35,36]$. More studies are required to evaluate the chilling-injury sensitivity of the 'Orito' cultivar after longer cold storage.

As previously mentioned, all of the identified compounds remained stable during shelf-life storage. This behavior could be attributed to the non-stimulation of these enzymes under shelf-life conditions. For instance, PAL activity and concentration decreased when mandarin fruits were exposed to non-chilling temperatures [36]. 


\section{Conclusions}

Based on the results of this study, 'Orito' fruits maintained their phytochemical composition during three-day shelf-life storage after cold storage, while the content of some betalains, phenolic acids and lignans increased during cold storage. These results, along with a previous study [13], showed that the marketability of prickly pear fruit from the 'Orito' cultivar can be possible up to 28 days after harvesting. Further investigation is required to evaluate the changes on the (poly)phenolic and betalain profile of these cactus fruits under other postharvest conditions, such as modified atmosphere packaging. In addition, assessing the role of well-known enzymes in the metabolism of these phytochemicals may lead to mechanistic insights useful to better handling postharvest reactions in CAM fruits.

Supplementary Materials: The following are available online at https://www.mdpi.com/article/ 10.3390/foods11020160/s1, Table S1: Gradient used in HPLC analysis; Table S2: Gradient used in HPLC-DAD/MS/MS analysis.

Author Contributions: Conceptualization, P.M. and F.H.; methodology, A.T.S. and M.R.B.; software, A.B.-S.; validation, A.T.S., P.L., F.H. and M.R.B.; formal analysis, L.A.-C. and A.B.-S.; investigation, L.A.-C. and F.H.; resources, A.T.S. and M.R.B.; data curation, A.B.-S.; writing-original draft preparation, L.A.-C.; writing-review and editing, P.M., F.H. and P.L.; visualization, A.T.S.; supervision, M.R.B.; funding acquisition: not applicable. All authors have read and agreed to the published version of the manuscript.

Funding: iNOVA4Health—UIDB/04462/2020 and UIDP/04462/2020—a program financially supported by Fundação para a Ciência e Tecnologia/Ministério da Ciência, Tecnologia e Ensino Superior, through national funds, and the program CIEPQPF (PEst-C/EQB/UI0102/2019 and UIDB/00102/2020) are acknowledged. Funding from the INTERFACE Program, through the Innovation, Technology and Circular Economy Fund (FITEC), is gratefully acknowledged. We acknowledge the financial support from Fundação para a Ciência e Tecnologia and Portugal 2020 to the Portuguese Mass Spectrometry Network (LISBOA-01-0145-FEDER-402-022125).

Institutional Review Board Statement: Not applicable.

Informed Consent Statement: Not applicable.

Data Availability Statement: Not applicable.

Conflicts of Interest: The authors declare no conflict of interest.

\section{References}

1. Andreu, L.; Nuncio-Jáuregui, N.; Carbonell-Barrachina, Á.A.; Legua, P.; Hernández, F. Antioxidant properties and chemical characterization of Spanish Opuntia ficus-indica Mill. cladodes and fruits. J. Sci. Food Agric. 2018, 98, 1566-1573. [CrossRef]

2. Mena, P.; Tassotti, M.; Andreu, L.; Nuncio-Jáuregui, N.; Legua, P.; Del Rio, D.; Hernández, F. Phytochemical characterization of different prickly pear (Opuntia ficus-indica (L.) Mill.) cultivars and botanical parts: UHPLC-ESI-MSn metabolomics profiles and their chemometric analysis. Food Res. Int. 2018, 108, 301-308. [CrossRef]

3. $\quad$ El-Mostafa, K.; El Kharrassi, Y.; Badreddine, A.; Andreoletti, P.; Vamecq, J.; El Kebbaj, M.S.; Latruffe, N.; Lizard, G.; Nasser, B.; Cherkaoui-Malki, M. Nopal cactus (Opuntia ficus-indica) as a source of bioactive compounds for nutrition, health and disease. Molecules 2014, 19, 14879-14901. [CrossRef]

4. Andreu-Coll, L.; Cano-Lamadrid, M.; Noguera-Artiaga, L.; Lipan, L.; Carbonell-Barrachina, Á.A.; Rocamora-Montiel, B.; Legua, P.; Hernández, F.; López-Lluch, D. Economic estimation of cactus pear production and its feasibility in Spain. Trends Food Sci. Technol. 2020, 103, 379-385. [CrossRef]

5. Saenz, C. Processing technologies: An alternative for cactus pear (Opuntia spp.) fruits and cladodes. J. Arid Environ. 2000, 46, 209-225. [CrossRef]

6. FAO (Food and Agricultural Organization). Ecologia Del Cultivo, Manejo Y Usos Del Nopal; Inglese, P., Mondragon, C., Nefzaoui, A., Sáenz, C., Eds.; FAO: Roma, Italy, 2018; ISBN 9789251304945.

7. Serra, A.T.; Poejo, J.; Matias, A.A.; Bronze, M.R.; Duarte, C.M.M. Evaluation of Opuntia spp. derived products as antiproliferative agents in human colon cancer cell line (HT29). Food Res. Int. 2013, 54, 892-901. [CrossRef]

8. Ochoa-Velasco, C.E.; Guerrero-Beltrán, J.Á. The effects of modified atmospheres on prickly pear (Opuntia albicarpa) stored at different temperatures. Postharvest Biol. Technol. 2016, 111, 314-321. [CrossRef] 
9. Valero, D.; Serrano, M. Postharvest Biology and Technology for Preserving Fruit Quality; CRC Press: Boca Raton, FL, USA, 2010; ISBN 9781439802663.

10. Corrales-García, J.; Andrade-rodríguez, J.; Bernabé-Cruz, E. Response of six cultivars of tuna fruits to cold storage. J. Prof. Assoc. Cactus Dev. 1997, 2, 160-168.

11. Díaz-Mula, H.M. Bioactive Compounds, Antioxidant Activity and Quality of Plum and Sweet Cherry Cultivars as Affected by Ripening on-tree, Cold Storage and Postharvest Treatments. Ph.D. Thesis, Universidad Miguel Hernández de Elche, Elche, Spain, 2011.

12. Paul, V.; Pandey, R.; Srivastava, G.C. The fading distinctions between classical patterns of ripening in climacteric and nonclimacteric fruit and the ubiquity of ethylene-An overview. J. Food Sci. Technol. 2012, 49, 1-21. [CrossRef]

13. Andreu-Coll, L.; García-Pastor, M.E.; Valero, D.; Amorós, A.; Almansa, M.S.; Legua, P.; Hernández, F. Influence of storage on physiological properties, chemical composition, and bioactive compounds on cactus pear fruit (Opuntia ficus-indica (1.) mill.). Agriculture 2021, 11, 62. [CrossRef]

14. Zuzunaga, M.; Serrano, M.; Martinez-Romero, D.; Valero, D.; Riquelme, F. Comparative Study of Two Plum (Prunus salicina Lindl.) Cultivars during Growth and Ripening. Food Sci. Technol. Int. 2001, 7, 123-130. [CrossRef]

15. Minas, I.S.; Forcada, C.F.; Dangl, G.S.; Gradziel, T.M.; Dandekar, A.M.; Crisosto, C.H. Discovery of non-climacteric and suppressed climacteric bud sport mutations originating from a climacteric Japanese plum cultivar (Prunus salicina lindl.). Front. Plant Sci. 2015, 6, 316. [CrossRef]

16. Katsinas, N.; Bento Da Silva, A.; Enríquez-De-Salamanca, A.; Fernández, N.; Bronze, M.R.; Rodríguez-Rojo, S. Pressurized Liquid Extraction Optimization from Supercritical Defatted Olive Pomace: A Green and Selective Phenolic Extraction Process. ACS Sustain. Chem. Eng. 2021, 9, 5590-5602. [CrossRef]

17. Addinsoft, S.A.R.L. XLSTAT Software 2010; Addinsoft: Barcelona, Spain, 2010.

18. Petruk, G.; Illiano, A.; Del Giudice, R.; Raiola, A.; Amoresano, A.; Rigano, M.M.; Piccoli, R.; Monti, D.M. Malvidin and cyanidin derivatives from açai fruit (Euterpe oleracea Mart.) counteract UV-A-induced oxidative stress in immortalized fibroblasts. J. Photochem. Photobiol. B Biol. 2017, 172, 42-51. [CrossRef] [PubMed]

19. Benayad, Z.; Martinez-Villaluenga, C.; Frias, J.; Gomez-Cordoves, C.; Es-Safi, N.E. Phenolic composition, antioxidant and anti-inflammatory activities of extracts from Moroccan Opuntia ficus-indica flowers obtained by different extraction methods. Ind. Crops Prod. 2014, 62, 412-420. [CrossRef]

20. El-Hawary, S.S.; Sobeh, M.; Badr, W.K.; Abdelfattah, M.A.O.; Ali, Z.Y.; El-Tantawy, M.E.; Rabeh, M.A.; Wink, M. HPLCPDA-MS/MS profiling of secondary metabolites from Opuntia ficus-indica cladode, peel and fruit pulp extracts and their antioxidant, neuroprotective effect in rats with aluminum chloride induced neurotoxicity. Saudi J. Biol. Sci. 2020, 27, $2829-2838$. [CrossRef] [PubMed]

21. García-Cayuela, T.; Gómez-Maqueo, A.; Guajardo-Flores, D.; Welti-Chanes, J.; Cano, M.P. Characterization and quantification of individual betalain and phenolic compounds in Mexican and Spanish prickly pear (Opuntia ficus-indica L. Mill) tissues: A comparative study. J. Food Compos. Anal. 2019, 76, 1-13. [CrossRef]

22. Mata, A.; Ferreira, J.P.; Semedo, C.; Serra, T.; Duarte, C.M.M.; Bronze, M.R. Contribution to the characterization of Opuntia spp. juices by LC-DAD-ESI-MS/MS. Food Chem. 2016, 210, 558-565. [CrossRef] [PubMed]

23. MassBank. Available online: https://massbank.eu/MassBank/ (accessed on 1 March 2021).

24. Phytohub. Available online: https://phytohub.eu/ (accessed on 1 March 2021).

25. MacRae, W.D.; Towers, G.H.N. Biological activities of lignans. Phytochemistry 1984, 23, 1207-1220. [CrossRef]

26. Kassuya, C.A.L.; Leite, D.F.P.; De Melo, L.V.; Rehder, V.L.C.; Calixto, J.B. Anti-inflammatory properties of extracts, fractions and lignans isolated from Phyllanthus amarus. Planta Med. 2005, 71, 721-726. [CrossRef] [PubMed]

27. Robbins, R.J. Phenolic acids in foods: An overview of analytical methodology. J. Agric. Food Chem. 2003, 51, 2866-2887. [CrossRef] [PubMed]

28. Rashmi, H.B.; Negi, P.S. Phenolic acids from vegetables: A review on processing stability and health benefits. Food Res. Int. 2020, 136, 109298. [CrossRef] [PubMed]

29. Albano, C.; Negro, C.; Tommasi, N.; Gerardi, C.; Mita, G.; Miceli, A.; de Bellis, L.; Blando, F. Betalains, phenols and antioxidant capacity in cactus pear [opuntia ficus-indica (L.) mill.] fruits from Apulia (South Italy) genotypes. Antioxidants 2015, 4, 269-280. [CrossRef]

30. Hernández, F.; Andreu-Coll, L.; Cano-Lamadrid, M.; López Lluch, D.; Carbonell-Barrachina, Á.A.; Legua, P. Valorization of Prickly Pear [Opuntia ficus-indica (L.) Mill]: Nutritional Composition, Functional Properties and Economic Aspects. In Invasive Species-Introduction Pathways, Economic Impact, and Possible Management Options; IntechOpen: London, UK, 2020 ; pp. 1-9.

31. Yoo, H.; Widhalm, J.R.; Qian, Y.; Maeda, H.; Cooper, B.R.; Jannasch, A.S.; Gonda, I.; Lewinsohn, E.; Rhodes, D.; Dudareva, N. An alternative pathway contributes to phenylalanine biosynthesis in plants via a cytosolic tyrosine:phenylpyruvate aminotransferase. Nat. Commun. 2013, 4, 2833. [CrossRef]

32. Jiang, Y.; Joyce, D.C. ABA effects on ethylene production, PAL activity, anthocyanin and phenolic contents of strawberry fruit. Plant Growth Regul. 2003, 39, 171-174. [CrossRef]

33. Tomás-Barberan, F.A.; Ferreres, F.; Gil, M.I. Antioxidant phenolic metabolites from fruit and vegetables and changes during postharvest storage and processing. Stud. Nat. Prod. Chem. 2000, 23, 739-795. [CrossRef] 
34. Ramírez-Ramos, M.; Medina-Dzul, K.; García-Mateos, R.; Corrales-García, J.; Ybarra-Moncada, C.; Castillo-González, A.M. Nutraceutical components, antioxidant activity, and color of 11 varieties of prickly pear (Opuntia sp.). J. Appl. Bot. Food Qual. 2018, 91, 211-218. [CrossRef]

35. Sogvar, O.B.; Rabiei, V.; Razavi, F.; Gohari, G. Phenylalanine alleviates postharvest chilling injury of plum fruit by modulating antioxidant system and enhancing the accumulation of phenolic compounds. Food Technol. Biotechnol. 2020, 58, 433-444. [CrossRef]

36. Sanchez-Ballesta, M.T.; Lafuente, M.T.; Zacarias, L.; Granell, A. Involvement of phenylalanine ammonia-lyase in the response of Fortune mandarin fruits to cold temperature. Physiol. Plant. 2000, 108, 382-389. [CrossRef] 